\section{CHANGE IN THE STANDARD THAI HIGH TONE: AN ACOUSTIC STUDY}

\section{Phanintra Teeranon ${ }^{1}$ Rungwimol Rungrojsuwan ${ }^{2}$}

\begin{abstract}
Standard Thai tones are divided into two categories; namely, level tones (mid tone, low tone, and high tone) and contour tones (falling tone and rising tone).

The Thai high tone was found to have changed its height and shape between the years 1911 and 2006 (Bradley 1911; Abramson 1962; Tumtavitikul 1992; Morén and Zsiga 2006). The tone changed its shape from mid falling (1911) to high level (1962), and then to mid rising (2006).
\end{abstract}

This study attempts to show that the high tone in Standard Thai is changing its phonetic characteristics from high level to mid rising. The informants were divided into two age groups: over-sixty and undertwenty. Each age group was comprised of twenty informants. The Praat program was used to conduct an acoustic analysis. The results show that the high tone shape in the over-sixty group is high level, but it is mid rising in the under-twenty group. It has also been found that the present characteristic of the high tone is similar to that of the rising tone. It is argued whether the Standard Thai high tone should be categorized as a contour tone. Standard

\footnotetext{
${ }^{1}$ Lecturer, School of Liberal Arts, Mae Fah Luang University, Chiang Rai, Thailand

${ }^{2}$ Lecturer, School of Liberal Arts, Mae Fah Luang University, Chiang Rai, Thailand
}

Thai high tone variations indicate the plausibility of observing an ongoing change. In addition, some ongoing change in the falling tone is also discussed.

\section{Introduction}

Thai is classified as a tonal language, a language that uses tone to convey word meaning. For example, [maa] means 'to come' but [máa] means 'horse'. Based on an acoustic study and phonological analysis (Abramson 1962, 1975), there are five distinctive tones in Standard Thai ${ }^{3}$ : mid tone, low tone, falling tone, high tone and rising tone. Acoustically, each Thai tone phonetic characteristic is well-defined by fundamental frequency $\left(\mathrm{F}_{0}\right)$ shape. $\mathrm{F}_{0}$ shape is identified by $F_{0}$ height (the starting point of $\mathrm{F}_{0}$ ) and $\mathrm{F}_{0}$ direction (the movement of $F_{0}$ ). The $F_{0}$ shape is the basis for grouping Thai tones into two categories, namely level or static tones, and contour or dynamic tones.

The level tone category is comprised of mid tone, low tone, and high tone. The contour tone category is comprised of falling tone and rising tone.

All tone shapes can be described by using the five-tone scale pitch system to represent their $\mathrm{F}_{0}$ height and direction. And to convert their shapes into the five-tone scale pitch system, the mid tone is [33], low tone is [21], falling tone is [43], high

\footnotetext{
${ }^{3}$ Standard Thai is the official language spoken by educated speakers in every part of Thailand, used in news broadcasts on radio and television, taught in school, and described in grammar books and dictionaries (Tingsabadh and Abramson 1993). We use the term Standard Thai because it was classified as a variety of Central Thai on the basis of tone system and tone split (Gedney 1972).
} 
tone is [44 or 45], and rising tone is [323].

Over the past several decades, an acoustic study of Standard Thai tones has been an interesting topic for many linguists. Linguists of earlier studies examined Standard Thai tones on isolated monosyllables (Abramson 1962, 1975, 1979; Erickson 1974). Then Hiranburana (1972), Potisuk et al. (1994) and Tingsabadh and Deeprasert (1997) proposed testing the tones in stressed and unstressed syllables of connected speech. Recently, Gandour et al. (1999) and Teeranon (2002b) have made advances. They studied stressed and unstressed syllables in tempo and rhythmic units of speech. Most of these studies confirmed that Standard Thai tones are: mid tone is [33], low tone is [21], falling tone is [43], high tone is [44 or 45], and rising tone is [323]. The findings also showed that the $\mathrm{F}_{0}$ shape of Standard Thai tones can vary by context, e.g. tone variants in stressed syllables, tone variants in unstressed syllables. It can be said that the studies mentioned above were all interested in the synchronic study of Thai tones; they were seemingly focused on tone variations in various contexts. There are only a few studies (Panroj 1991; Teeranon 2002a, 2002c) seemingly interested in the diachronic study of Thai tones or variations of Thai tones in apparent time. These studies discovered that the $F_{0}$ shape of tones can vary by apparent time; they used different age group to represent the past and the present time. Panroj (1991) found that Thai tones tend to be different from time to time. However, Panroj (1991) never stated clearly that the high tone changed its $\mathrm{F}_{0}$ height and direction from high level [44 or 45] to mid rising [334]. An examination of change in the Standard Thai high tone was later conducted by the documented research method (Teeranon 2002a). There was also a study (Teeranon 2002c) which tried to prove the change in the Standard Thai high tone spoken by two generations: an older generation and younger generation. But she used a small number of informants, only three from each group. It can be observed that previous work was based on small numbers of informants as prior to the advent of computers, measuring glottal periods as seen in waveforms or measuring across harmonics in narrow-band spectrograms was time-consuming. The other point that can be obviously seen from the $F_{0}$ shapes of tones found in each study is, moreover, presented by using the overall mean. The variation of $F_{0}$ of tones, not just for high tones, seems to be undervalued. That is to say, the phonetic variations of tones seem to be undervalued. To demonstrate that high tone change is observable, $F_{0}$ shapes of high tones were also presented by their variants. As mentioned in Aitchison (2001: 43), Labov recognized, the variation and fuzziness which so many linguists try to ignore are quite often indications that changes are in progress.

In order to confirm the change of the high tone, an acoustic study of Standard Thai tones and their variants was analyzed using measurements of $\mathrm{F}_{0}$ on isolated monosyllables spoken by informants of two generations: those over sixty years old and those under twenty years old ${ }^{4}$. The reason for studying the change in these two age groups is that the over-sixty group represents the past, while the under-twenty group represents the present and the future.

\footnotetext{
${ }^{4}$ From now on, we call them the over-sixty group and the under-twenty group, respectively.
} 


\section{Preliminary background: The change of Standard Thai high tone}

According to the $\mathrm{F}_{0}$ shape of the high tone during the past century, starting from 1911 to 2007 , the development of the high tone is divided into three periods 5 .

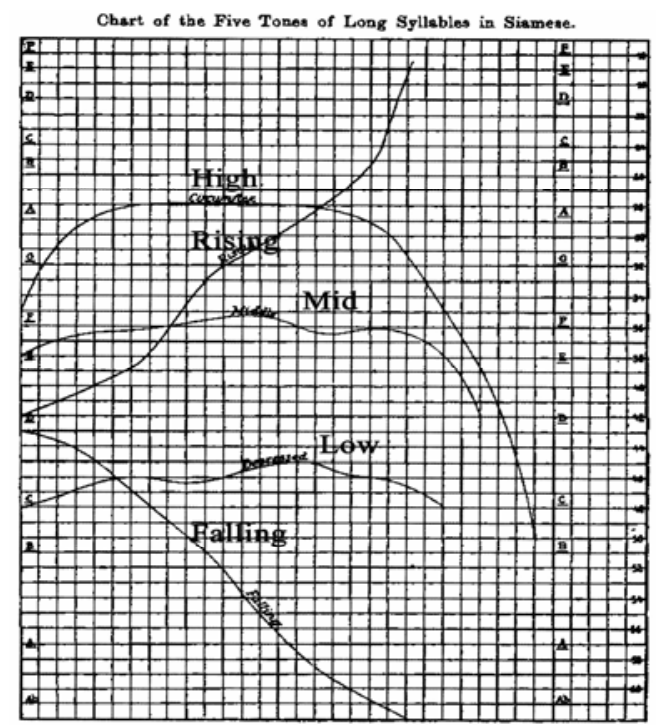

Figure 1: $F_{0}$ shapes of Standard Thai tones in the first period (adapted from Bradley 19116)

The phonetic characteristics of Standard Thai tones first began to be recognized in

\footnotetext{
${ }^{5}$ Actually, there have been many studies of Standard Thai tones done by linguists in each period. But we chose to present only one work in each period. The rule for selection is that the age of informants must not be more than twenty-five years old. Therefore, they are sixty-five years old today; in other words, they are in the same generation as our over-sixty group of informants.

${ }^{6}$ Though C.B. Bradley conducted the research in 1908, his paper was published in 1911 .
}

1911 by C. B. Bradley. Bradley (1911) used a kymographic recording of Thai. The informant may have been himself, an English-Thai bilingual. It was observed that the high tone was high falling, which makes it similar to the falling tone of the present time. The rising tone began at midpitch before steadily increasing. As a result, when comparing the high tone and rising tone, their shapes are totally different in $\mathrm{F}_{0}$ height and direction (see Figure 1).

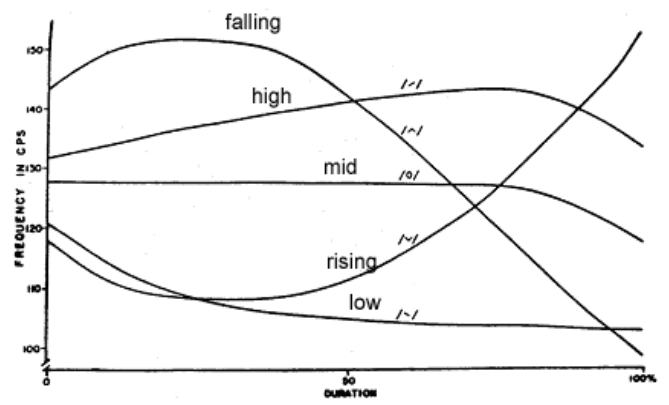

Figure 2: $F_{0}$ shapes of Standard Thai tones in the second period (Abramson 1962)

From 1962-1975, while the rising tone showed a slight change, the shape of the high tone showed much greater change. In this period, the rising tone began at midpoint then stayed low before rising, but the high tone gradually increased from the high level with a slight fall at the end (Abramson 1962, 1975; Erickson 1974). The high tone was seemingly changing from contour to level. And it is found that the falling tone shape looked very much like the high tone in the first period (see Figure 2). In recent times, the high tone has been noticed to change its shape again from high level to mid rising (see Figure 3) (Abramson 1979; Chuwarahawong 2000; Morén and Zsiga 2006; Panroj 
1991; Tumtavitikul 1992; Potisuk et al. 1994; Tingsabadh and Deeprasert 1997; Teeranon 2002a, 2002b, 2002c). Its shape looks like a rising tone.
In order to make a comparison between high tone shapes in each period, we converted each figure and set up a table to present the change.

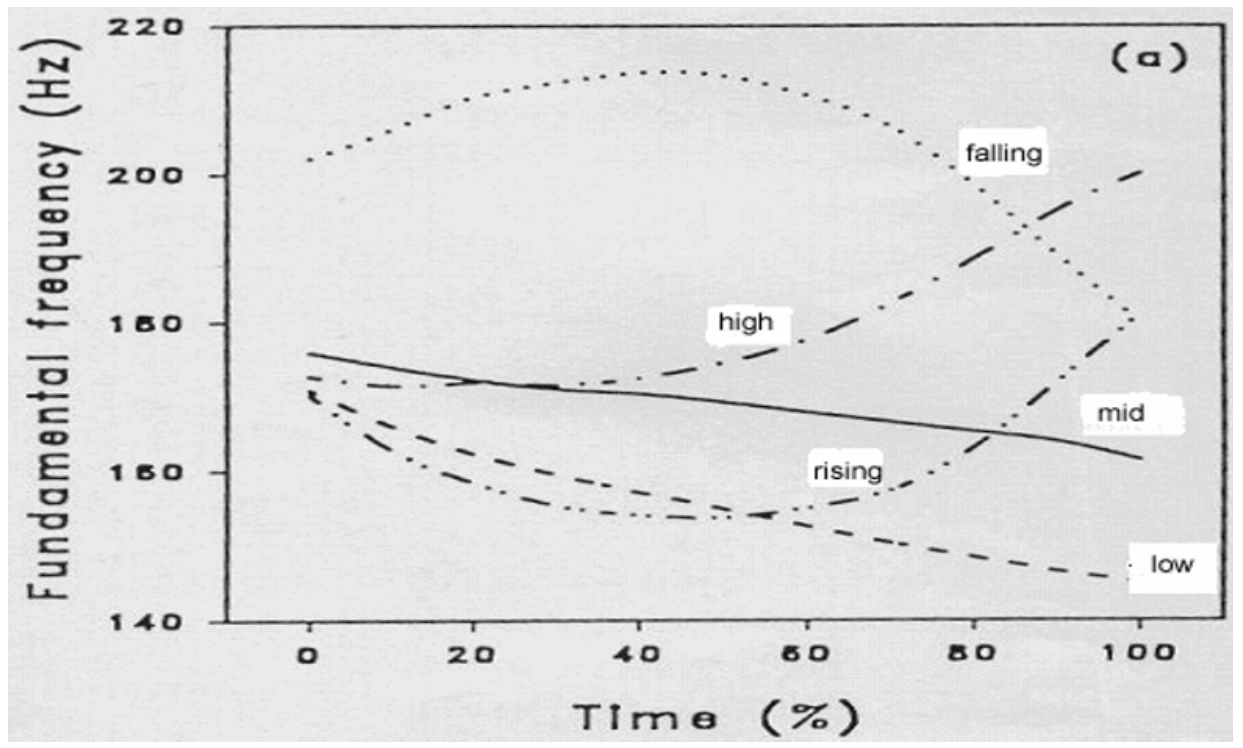

Figure 3: $F_{0}$ shapes of Standard Thai tones in the third period (Potisuk et al. 1994)

Table 1 consists of six columns. The first column represents the period which is divided by high tone shape. The second column represents the authors and the year they conducted their research. Some social factors, sex and age, are represented in the third and fourth columns. The fifth column represents the tone shapes converted from the original. Five lines in this column were drawn. Each line represents $F_{0}$ values. The lowest $\mathrm{F}_{0}$ values are represented by the lowest line (or number 1 on a Five-scale numerical system) and the highest line represents the highest $\mathrm{F}_{0}$ values (or number 5 on a Five-scale numerical system). Then the $\mathrm{F}_{0}$ values in the fifth column have been converted to a numerical system in the sixth column. 
Table 1 The change of Standard Thai high tone shape

\begin{tabular}{|c|c|c|c|c|c|}
\hline (1) Periods & (2) Authors & $\begin{array}{c}\text { (3) Sex of } \\
\text { informants }\end{array}$ & $\begin{array}{c}\text { (4) Age of } \\
\text { informants }\end{array}$ & $\begin{array}{c}\text { (5) Five-scale } \\
\text { tone stick } \\
\text { system }\end{array}$ & $\begin{array}{c}\text { (6) Five-scale } \\
\text { tone numerical } \\
\text { system }\end{array}$ \\
\hline 1 & Bradley (1911) & male & 65 & \multirow{2}{*}{4} \\
\hline & Abramson (1962) & male & $23-25$ & \\
\hline
\end{tabular}

In the first period, the high tone is high falling $[442]^{7}$. The tone shape starts from a high pitch and rises before falling to a low pitch level. Its falling curve shows that the high tone is a contour tone.

Fifty-five years later, in the second period, the tone shape is high level [ 44 of 45]. The tone shape starts from a high pitch and rises steadily. However, its slightly falling contour at the end still remains. Its shape is becoming less contoured compared with the first period.

In the third period, the high tone starts from mid pitch and levels off before rising. It is noted that this shape is similar to that of the rising tone (Abramson 1979). Obviously, between the first and the third periods, the high tone shape totally changes. That is to say, high tone height has

\footnotetext{
${ }^{7}$ All numbers in the sixth column are derived from $\mathrm{F}_{0}$ values.
}

changed from high to mid, and its direction has changed from falling to rising.

\section{Language data}

The language data used as test tokens were drawn from Standard Thai belonging to the Tai-Kadai language family. The language has a repertoire of nine monopthongal vowels /i, i, u, e, ə, o, $\varepsilon, a$, / with vowel length distinction. But all the test words contained the vowel /aa/. The reason for selecting /aa/ was to avoid an effect of intrinsic pitch. As it has been confirmed that different vowel heights can cause different $\mathrm{F}_{0}$ values (Whalen and Levitt 1995), high vowels, e.g. /i/, tend to have higher $\mathrm{F}_{0}$ values than low vowels, e.g. /a/. Therefore, only the low mid long vowel, /aa/, was selected for the study. 
Forty informants were chosen. As language change can be affected by age, these informants were then divided into two groups: twenty informants were over sixty years old and another twenty informants were under twenty years old. The age of the informants was used to help further confirm the claim of high tone change. It is believed that age is one of the most important factors to test the change in apparent time (Chambers 1995; Labov 1994). The informants in the over-sixty group represent the past, while the undertwenty group represent the present and the future.

Three sets of test tokens were selected for the /aa/ vowel with various kinds of initial consonants as follows:

\begin{tabular}{|l|l|l|}
\hline Set $\mathbf{1}$ & Set 2 & Set 3 \\
\hline $\begin{array}{c}\text { khaa 'logged in, remain } \\
\text { embedded' }\end{array}$ & naa 'rice field' & faa 'a note' \\
\hline khàa 'galangal' & (nój) nàa 'custard apple' & $\begin{array}{l}\text { fâa 'palm (of the hand), sole } \\
\text { (of the foot)' }\end{array}$ \\
\hline khâa 'servant, slave' & nâa 'face' & fâa 'scum' \\
\hline kháa 'to trade' & náa 'aunt' & fáa 'sky' \\
\hline khăa 'leg' & năa 'thick' & făa 'pot cover' \\
\hline
\end{tabular}

\section{Methodology}

After preparing all the meaningful test tokens, the informants were asked to pronounce each test word in isolation five times. They pronounced each time at a moderate tempo, with a pause after each token. The number of total test tokens was three thousand (twenty informants $\mathrm{x}$ two age groups $\mathrm{x}$ five tokens $\mathrm{x}$ three sets $\mathrm{x}$ five times). The recordings were made directly on to Cooledit Pro in the computer. Cooledit Pro was also used when each sound was segmented. The Praat program version 4.2.09 was used to analyze the $\mathrm{F}_{0}$ of isolated words. The frequency at five points of time for each vowel was selected for measurement, at $0 \%, 25 \%, 50 \%, 75 \%$ and $100 \%$. Microsoft Excel 2003 was the tool used to analyze and plot graphs of the overall means $(\overline{\mathrm{x}})$ of $\mathrm{F}_{0}$. And to study high tone variants, $F_{0}$ values were then converted to semitones to have something more like pitch before making a comparison. Line graphs were drawn as seen in Figure 4 to Figure 7.

To analyze the variants, six hundred tokens out of three thousand were selected by using a random sampling method ${ }^{8}$. The constraints on the random sampling were: 1) there are twenty informants in each age group, 2) only the high tone of the three sets was selected for analysis, and then 3 )

\footnotetext{
${ }^{8}$ Pierrehumbert (2001) indicates that a small random sample of the words can be reliable.
} 
five-randomized tokens were selected. In each age group, the same shape of high tone was classified and categorized. The percentage of frequency distributions of each variant was calculated.

\section{Results}

The overall mean of Thai high tones in the over-sixty group

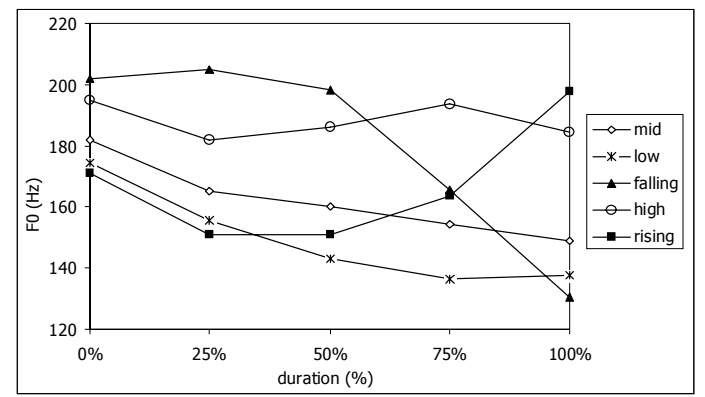

Figure 4: $F_{0}$ shapes of Standard Thai tones in the over-sixty group

In Figure 4, the results show that the Thai high tone of the over-sixty group is similar to that found by Abramson (1962). The high tone is high level [44]. It begins with a high pitch, then steadily rises before slightly falling. This is because the informants represent the second period of tone change (see Table 1). In comparison, the rising tone begins with a lower pitch then slightly falls before rising.
The overall mean of Thai high tones in the under-twenty group

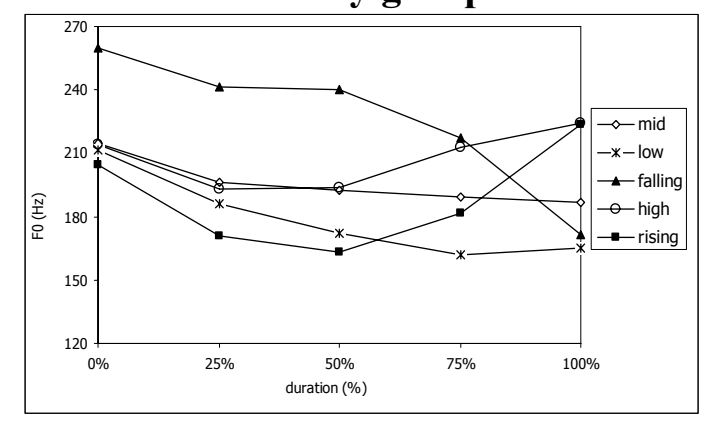

Figure 5: $F_{0}$ shapes of Standard Thai tones in the under-twenty group

As seen in Figure 5, the under-twenty high tone shape became [334], which is more similar to the rising tone. And the starting point of the pitch for the high tone and rising tone is lower than that of the oversixty group. Both tones seem to be more contoured, sharply falling and rising. The result confirms the gradual change of the Thai high tone from high level [44] to mid rising [334]. The findings support the high tone change reported by Abramson (1979), Panroj (1991), Tumtavitikul (1992), and Teeranon (2002a, 2002b, 2002c).

As all Thai tones are well-defined by $\mathrm{F}_{0}$ shape, the shape of the high tone is obviously changed to be more contoured. This leads to the question of whether we should place the high tone as a contour tone instead of a level tone. This confirms an observation made by Abramson (1978, 1997) that the tone percept can be improved by $\mathrm{F}_{0}$ movement.

It was also found that the mid tone and low tone are virtually the same shape but at different heights in the voice range.

In addition, it was shown that the falling tone is changing. In comparison with the 
over-sixty group, falling tone shape in the under-twenty group levels off at a higher level for half of the time before gradually dropping (see Figure 5). This result supports the findings of Lertthana (2005) that the falling tone is changing. And the change of the falling tone can be used to confirm some mechanisms in directionality of tone change proposed by Pittayaporn (2007): contour reduction, peak sliding, and perceptual maximization. That is to say, the falling tone has changed its peak sliding; its $\mathrm{F}_{0}$ height moves up to higher values. And to compensate for the higher $\mathrm{F}_{0}$ height, the falling tone shape has changed to be less contoured to enhance the perception of a falling tone.

\section{High tone variants in the over-sixty group and in the under-twenty group}

\section{The shape of high tone variants}

After six hundred tokens out of three thousand were selected for analysis, then they were categorized by grouping the same shapes of high tone together. In the over-sixty group, it was found that there are three variants of high tone: high level [45], high level with slightly falling [44], and rising [434] (see Figure 6). In the under-twenty group, it was found also that there are three variants of high tone but the height and direction are a bit different. The three variants are high level [34], rising with slightly falling [322], and rising [334] (see Figure 7). When compared Figure 6 and Figure 7, pitch height in the undertwenty group is lower than in the oversixty group.

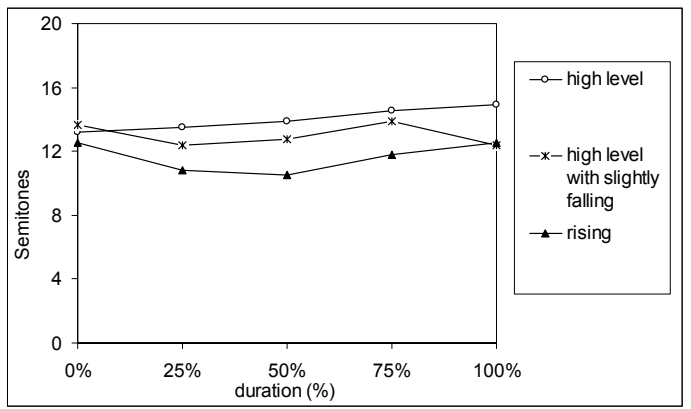

Figure 6: High tone variants in the oversixty group

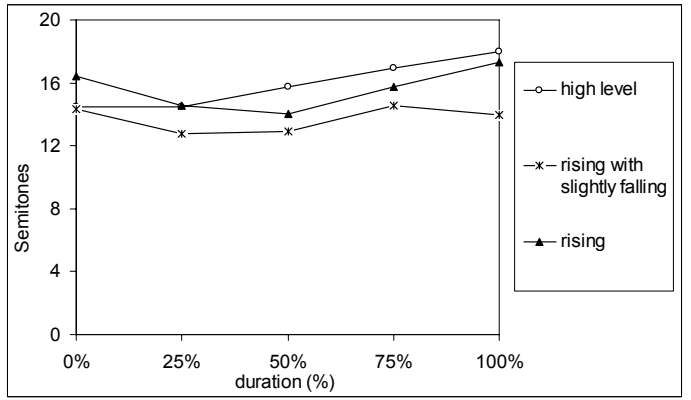

Figure 7: High tone variants in the under-twenty group

\section{Frequency distributions of high tone variants}

In the over-sixty group, there are three variants: high level [45], high level with slightly falling [44], and rising [434]. It is shown that the most prominent high tone variant is high level with slightly falling [44], accounting for 78\%. High level [45] and rising shape [434] frequency distributions amounted to $11 \%$ (see Figure 8). 


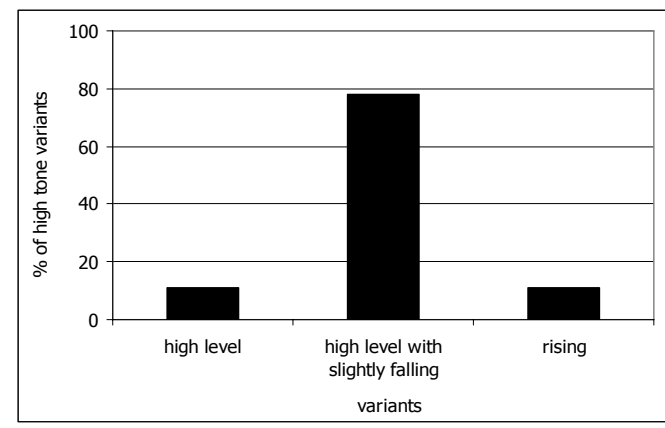

Figure 8: Percentage (\%) of frequency distributions of high tone variants in the over-sixty group

In the under-twenty group, there are also three variants: high level [34], rising with slightly falling [322], and rising [334]. The variant that appears to have the highest frequency distribution is rising [334] shape, accounting for $78 \%$. Rising with slightly falling [322] shape distribution amounted to $28 \%$. And high level [34] distribution amounted to 2\% (see Figure 9).

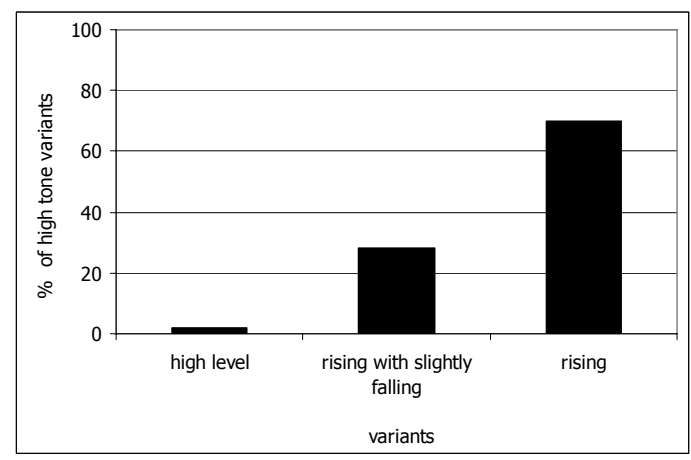

Figure 9: Percentage (\%) of frequency distributions of high tone variants in the under-twenty group

It is obvious that the pitch height of the high tone is moving down from high to mid. And the two high tone variations, high level-like shape and rising shape, appear in both groups. The high level-like shape is seemingly prominent in the oversixty group. The rising shape, which is the most prominent variation of the undertwenty group, also appears in the oversixty group but at a smaller percentage. In other words, the high level-like shape is not a prominent variation for the undertwenty group, but rising is. As rising is one variation in the over-sixty group, it is plausible that the high tone has changed its shape from high level [44 45] to mid rising. The high tone variation found in this research indicates a change in progress. It is not an abrupt change, but a gradually change. And ongoing change is observable. Based on Labov (1994), the findings confirm that variations and fuzziness show observable change.

\section{Conclusion}

Based on the findings, it can be concluded that the phonetic characteristics of the Standard Thai high tone have changed. The high tone shape has changed from high falling [442] in 1911 to high level [44 or 45], and at the present, the high tone shape is changing to rising contour [334]. And the high tone should be regrouped as a contour tone not a level tone. Moreover, high tone variants in each age group indicate the plausibility that the high tone is changing from high level shape to rising shape, and this change is observable.

Phonetic characteristics of the high tone and rising tone are becoming the same. Tone is used to distinguish word meanings. Therefore if the high tone and rising tone become the same, it will cause homophones. In order to avoid homophones, it is possible that the high tone or rising tone shape may change again. 


\section{Acknowledgements}

We are grateful to the Division of Research Services, Mae Fah Luang University for research funding. And we would like to express our gratitude to all our informants for their cooperation.

\section{References}

Abramson, A. S. 1962. The Vowels and

Tones of Standard Thai: Acoustical Measurements and Experiments.

Bloomington: Indiana University

Research Center in Anthropology,

Folklore and Linguistics, Publication

No.20.

---. 1975. The Tones of Central Thai: Some

Perceptual Experiments. Studies in

Thai Linguistics in Honor of William

J.Gedney, edited by J. G. Harris and J. R

Chamberlain, pp. 1-16. Bangkok: Central

Institute of English Language, Office of

State Universities.

---. 1978. Static and Dynamic Acoustic Cues in Distinctive Tones. Language and Speech 21: 319-325.

---. 1979. The Coarticulation of Tones: An Acoustic Study of Thai. Studies in Tai and Mon-Khmer Phonetics and Phonology in Honour of Eugénie J.A. Henderson, edited by T. L-Thongkum, P. Kullavanijaya, V. Panupong and K. Tingsabadh, pp. 1-9. Bangkok: Indigenous Languages of Thailand Research Project.

---. 1997. The Thai Tonal Space. Southeast Asian Linguistics Studies in Honour of Vichin Panupong, edited by A. S. Abramson, pp. 1-10. Bangkok: Chulalongkorn University Press.
Aitchison, J. 2001. Language Change: Progress or Decay? Cambridge: Cambridge University Press.

Bradley, C. B. 1911. Graphic Analysis of the Tone Accents of the Siamese Language. Journal of the American Oriental Society 31: 282-289.

Chambers, J. K. 1995. Sociolinguistic Theory: Linguistic Variation and Its Social Significance. Oxford: Blackwell.

Chuwarahawong, W. 2000. Tones in Bangkok Thai Spoken by the Thai, the Chao Zhou and the Sikhs. Unpublished M.A. Thesis, Chulalongkorn University.

Erickson, D. 1974. Fundamental Frequency Contours of the Thai Tones of Standard Thai. Pasaa 4: 1-25.

Gandour, J., A. Tumtavitikul, N. Satthamnuwong. 1999. Effects of Speaking Rate on the Thai Tones. Phonetica 56: 123-134.

Gedney, W. J. 1972. A Checklist for Determining Tones in Tai Dialects. Studies in Linguistics in Honor of George L. Trager, edited by M. E. Smith, pp. 423-438. The Hague: Mouton.

Hiranburana, S. 1972. Changes in the Pitch Contours of Unaccented Syllables in Spoken Thai. Tai Phonetics and Phonology, edited by J. G. Harris \& R. B. Noss, pp. 23-27. Bangkok: Central Institute of English Language, Office of State Universities.

Labov, W. 1994. Principles of Linguistic Change Volume 1: Internal Factors. Cambridge: Blackwell. 
Lertthana, A. 2005. Variations of the Falling Tone by Sex of Speaker in Bangkok Thai and Hearer's Attitudes. Unpublished M.A. Thesis, Thammasat University.

Morén, B. and E. Zsiga. 2006. The Lexical and Post-lexical Phonology of Thai Tones. Natural Language and Linguistic Theory 24.1: 113-178.

Panroj, P. 1991. Acoustic Characteristics of Tones in Bangkok Thai: Variation by Age Group. Unpublished M.A. Thesis, Chulalongkorn University.

Pierrehumbert, J. 2001. Exemplar Dynamics: Word Frequency, Lenition, and Contrast. Frequency Effects and the Emergence of Lexical Structure, edited by J. Bybee and P. Hopper, pp. 137-157. Amsterdam: John Benjamins.

Pittayaporn, P. 2007. Directionality of Tone Change. Proceedings of the $16^{\text {th }}$ International Congress of Phonetic Sciences, edited by J. Trouvain and W. J. Barry, pp. 1421-1424. Saarbrücken, Germany.

Potisuk, S., J. T. Gandour and M. P. Harper. 1994. $\mathrm{F}_{0}$ Correlates of Stress in Thai. Linguistics of the Tibeto-Burman Area 17.2: 1-27.

Teeranon, P. 2002a. Changes in Phonetic Characteristic of Thai High Tone (การ เปลี่ยนแปลงสัทลักษณะของวรรณยุกต์เสียงตรี ในภาษาไทย). Warasan Aksorasat, Silapakorn University (วารสารอักษร ศาสตร์ มหาวิทยาลัยศิลปากร) $24: 188-209$. (In Thai)
---. 2002b. Rhythmic Units and Tonal Variation in Thai. Manusya: Journal of Humanities 5.2: 16-29.

---. 2002c. Thai tones in the reigns of King Rama VI and King Rama IX (เสียง วรรณยุกต์ในภาษาไทยสมัยรัชกาลที่ 6 และ รัชกาลที่ 9). Journal of Language and Linguistics (ภาษาและภาษาศาสตร์) 21.1, 32-46. (In Thai)

Tingsabadh, K. and A. S. Abramson. 1993. Thai. Journal of the International Phonetic Association 23: 24-28.

Tingsabadh, K. and D. Deeprasert. 1997. Tones in Standard Thai Connected Speech. Southeast Asian Linguistic Studies in Honour of Vichin Panupong, edited by A. S. Abramson, pp. $297-$ 370. Bangkok: Chulalongkorn University Press.

Tumtavitikul, A. 1992. Consonant Onsets and Tones in Thai. Unpublished Doctoral Dissertation, University of Texas at Austin.

Whalen, D. H. and A. G. Levitt. 1995. The Universality of Intrinsic $\mathrm{F}_{0}$ of Vowels. Journal of Phonetics 23: 349-366. 